\title{
Does a financial crisis affect operating risk? Evidence from Polish listed companies ${ }^{1}$
}

\author{
Stawomir Kalinowski ${ }^{2}$, Marcin Puziak ${ }^{3}$
}

\begin{abstract}
In turbulent times of crisis the variability of both EBIT and operating revenue increase in comparison to a relatively stable post crisis period. The main aim of this paper is to investigate this relationship across these two periods. The hypothesis is that the degree of operating leverage (DOL) is significantly higher during the crisis period (2007-2010) than in the post-crisis period (2011-2015). Additionally the authors checked whether there were significant differences across defined industries and also verified whether all industries had responded in the same way to Financial Crisis as far as DOL is concerned. The main findings are: (a) The Financial Crisis of the years 2008-2009 significantly influenced the DOL of Polish stock companies; (b) There are substantial differences of the DOL across industries; (c) The DOL in the case of all industries investigated changed in the same direction when comparing two selected subperiods.
\end{abstract}

Key words: operating risk, financial crisis, Polish stock market, panel data analysis.

JEL codes: C33, D01, D22, G01, L21, L60, L70, L80, L90.

\section{Introduction}

Each business entity which takes decisions as to how to distribute resources is exposed to the risk of volatile conditions that affect the decision taken. For example, the choice of a specific basket of goods by the consumer ceases to be optimal if at the time of the purchase the price of at least one of the goods is different than at the moment when the decision was taken. Another example, which is a common experience of all companies, is a level of sales that diverges from the plan. If entrepreneurs sell less than planned they will make a lower operating profit and the decrease will bring a lower net profit. The relationships between the decreased levels may be more or less strongly correlated.

\footnotetext{
${ }^{1}$ Article received 15 January 2017, accepted 22 January 2018.

${ }^{2}$ Poznań University of Economics and Business, Faculty of Management, Department of Microeconomics, al. Niepodległości 10, Poznań, Poland, slawomir.kalinowski@ue.poznan.pl.

${ }^{3}$ Poznań University of Economics and Business, Faculty of Economics, Department of Microeconomics, al. Niepodległości 10, Poznań, Poland.
} 
A commonly accepted definition of the measure expressing the level of operating risk is (Arellano \& Scofield, 2014):

$$
D O L=\frac{\% \Delta E B I T}{\% \Delta R}
$$

where:

$D O L$ - degree of operating leverage,

$\% \triangle E B I T$ - relative change in EBIT (operating profit),

$\% \Delta R$ - relative change in revenues from sales that changes only under the influence of changes in sales volume; an analysis of operating leverage assumes a constant sales price.

Some basic transformations lead to the static version of the DOL formula:

$$
\begin{gathered}
D O L=\frac{\% \Delta E B I T}{\% \Delta R}=\frac{\Delta E B I T}{E B I T_{0}} \cdot \frac{R_{0}}{\Delta R}=\frac{\Delta Q(p-v)}{E B I T_{0}} \cdot \frac{Q p}{\Delta Q p}= \\
=\frac{Q(p-v)}{E B I T_{0}}=\frac{E B I T_{0}+F}{E B I T_{0}}=1+\frac{F}{E B I T_{0}},
\end{gathered}
$$

where:

$Q$ - quantity sold,

$p$ - price,

$v$ - unit variable cost,

$F$ - total fixed cost.

The ultimate formula shows that the higher the fixed costs, the higher is DOL and the higher the last year's operating profit the lower is the operating risk. Hence in the crisis period falling operating profits with fixed costs constant in the short run produce a rising DOL showing an increase of the operating risk. Afterwards, in the post-crisis period, companies experience rises of their EBIT and have time to reduce fixed costs. This leads authors to the main hypothesis: $\mathrm{H}_{1}$ - Operating risk measured by the degree of operating leverage is higher within the crisis period than in the post-crisis period.

The same static formula enables the presumption that companies more heavily burdened by fixed costs experience a higher operating risk:

$\mathrm{H}_{2}$ - The industries may be ordered according to the diminishing value of DOL as follows: electricity, gas and water supply (EGW), manufacturing, other services and trade.

A three-stage approach was adopted in this paper. First, the operating risk at the level of individual company was analyzed and the changes in DOL value between two subperiods: 2007-2010 were observed and compared, which is called the crisis period and 2011-2015 which is called the post-crisis period. The crisis period was expanded by incorporating the years 2007 and 2010. 
The authors intended to include the years directly before and after the crisis in order to capture the scale of downward and upward changes in the level of economic activity.

Second, the level of DOL in selected industries was observed and compared with the level of DOL for the entire research sample. Third, the reaction of companies in selected industries to the Financial Crisis was analyzed to seek an answer as to whether all selected industries reacted in the same way to such an impulse in terms of the DOL level. The paper is structured in the following way. Section 1 is devoted to a literature review. Section 2 deals with the research method. Section 3 discusses the database and variables used and their statistics. Results are presented and discussed in Section 4. The paper is closed with Conclusions.

\section{Literature review}

How the changes in the sales volume affect the change in operating profit depends on the scale of operating risk. Some authors define operating risk as the possibility of divergence of operating profit from its projected value (Brigham, 1995).

Estimating the degree of operating leverage based on empirical data was initially carried out by means of Lev's (1974) pioneering method. He examined the relationship between the levels of operating and financial leverage and the systematic risk for 121 US public companies from the sectors of: electricity, steel and fuel production. Another approach to DOL estimation was adopted by Mandelker and Rhee (1984). Starting with the treatment of the degree of operating leverage as a measure of elasticity they estimated the DOL using the regression equation (Mandelker \& Rhee, 1984, p. 50).

The second canonical approach to estimating the degree of operating leverage is O'Brien's and Vanderheiden's idea (1987). They proposed estimating DOL in two stages. First. they estimated the trend equation for natural logarithms of operating profit and sales revenue (O'Brien \& Vanderheiden, 1987, p. 47). In the second stage the estimated parameters independent from time viable of these two equations are combined in the next regression function. In this function the slope is the proxy for DOL.

An independent comparison of the methods $(\mathrm{M} \& \mathrm{R})$ and $(\mathrm{O} \& \mathrm{~V})$ was made by Dugan and Shriver (1992). Using the data from 245 companies in seven industries they counted their DOL using both methods. They adopted two hypotheses. First, the degrees of operating leverage for a given industry are the same for both methods. Secondly, the share of companies with a DOL factor higher than 1 is the same, regardless of the method used (Dugan \& Shriver, 1992, pp. 314-315). The first hypothesis was rejected and so was the second. The $(\mathrm{O} \& \mathrm{~V})$ method brought a much larger percentage of companies with $\mathrm{DOL}>1$. 
The inability to obtain financial data on the division of operating costs into fixed and variable ones forced the researchers who studied relationships between accounting measures of risk and market systematic risk to use a surrogate measure for the degree of operating leverage (proxies). Novy-Marx used the ratio of operating costs to assets (2011). Gulen, Xing and Zhang accepted the share of fixed assets in total assets as a surrogate variable (2011). None of these attempts brought DOL estimates that can be interpreted from a managerial point of view.

Considering the problem of the business cycle and operating risk it is worth mentioning the article of Gulen, Xing and Zhang once more (2011).They speculate that the expected returns of value firms covary more with recessions than the returns of growth firms as value firms are less flexible than growth firms in adjusting to recessionary shocks. Aguerrevere (2009) extends the model of Carlsson, Fisher and Giammarino (2004) to consider the effects of a firm's investment interaction on competitive markets. He found that the effect of competition on a firm's risk depends on the demand for the industry output, which is higher in times of economic growth and lower in the periods of crisis. The results of previous studies prove the impact of business cycles on the operating risk at company level.

\section{Research method}

This section describes the empirical method used in this paper to achieve the research goal. In order to estimate the level of DOL a general form of panel model was utilized:

$$
\% \Delta E B I T_{i t}=\beta_{0}+\beta_{1}\left(\% \Delta R_{i t}\right)+\alpha_{i}+v_{t}+v_{i t}
$$

where:

$$
\begin{aligned}
& i=1 \ldots N \\
& t=1 \ldots T \text {; } \\
& \% \triangle E B I T_{i t} \text { - yearly percentage change of operating profit }(E B I T) \text { of firm } i \text {; } \\
& \% \Delta R_{i t} \text { - yearly percentage change of operating revenue }(R) \text { of firm } i \text {; } \\
& \beta_{0} \text { - constant term; } \\
& \beta_{1} \text { - estimated parameter of DOL; } \\
& \alpha_{i} \text { - individual effects, part of variability of variable } \% \triangle E B I T_{i t} \text {, which is char- } \\
& \text { acteristic only to the firm } i \text { ( } N \text { is the total number of effects); } \\
& v_{t} \text { - time effects, part of variability of variable } \% \triangle E B I T_{i t} \text {, which is character- } \\
& \text { istic only to time period } t \text { ( } T \text { is the total number of effects); } \\
& v_{i t} \text { - disturbance term. }
\end{aligned}
$$


In case of panel models a couple of assumptions and tests before valid estimation begins must be made. First of all it was assumed that a one-way (individual) panel model would be used as the interest lies in a comparison of two subperiods (crisis period vs. post-crisis period). This means that time effects were not tested explicitly before a decision was made about the panel model, but after the estimations were made the differences in estimated DOLs were tested as to whether they are significant (which is explained later in the text).

Secondly the Hausman test was employed in order to decide whether fixed or random effects estimators for the equation (3) should be used. The null hypothesis assumes that the preferred model is the random effects model (Greene, 2000 ), which means that unique errors $\left(v_{i t}\right)$ are not correlated with regressors. Thirdly the Breusch-Pagan Lagrange multiplier test was employed (Breusch \& Pagan, 1980; Baltagi \& Li, 1990) to decide whether the random effects model or a pooled OLS regression should be used. The null hypothesis assumes that the variance across the companies analyzed is zero (which means no individual effects).

Finally the authors decided to estimate the equation (3) in three different forms. First, no individual effects were assumed and the equation (3) was constructed using a pooled model in the following form:

$$
\% \Delta E B I T_{i t}=\beta_{0}+\beta_{1}\left(\% \Delta R_{i t}\right)+v_{i t}
$$

where:

$i=1 \ldots N$

$t=1 \ldots T$

$\% \triangle E B I T_{i t}$ - yearly percentage change of operating profit (EBIT) of firm $i$;

$\% \Delta R_{i t}$ - yearly percentage change of operating revenue $(R)$ of firm $i$;

$\beta_{0}$ - constant term;

$\beta_{1}$ - estimated parameter of DOL;

$v_{i t}$ - disturbance term.

Secondly a random effects model was constructed, which results in the equation as follows::

$$
\% \Delta E B I T_{i t}=\beta_{0}+\beta_{1}\left(\% \Delta R_{i t}\right)+\alpha_{i}+v_{i t}+v_{i t}
$$

where:

$$
\begin{aligned}
& i=1 \ldots N ; \\
& t=1 \ldots . \ldots ; \\
& \% \Delta E B I T_{i t}-\text { yearly percentage change of operating profit }(E B I T) \text { of firm } i \\
& \% \Delta R_{i t}-\text { yearly percentage change of operating revenue }(R) \text { of firm } i ; \\
& \beta_{1} \text { - estimated parameter of DOL; } \\
& \alpha_{i}-\text { unknown intercept for each entity ( } N \text { firm-specific intercepts); } \\
& v_{i t}=\alpha_{i}+v_{i t}-\text { disturbance term. }
\end{aligned}
$$


Finally a fixed effects model was used, which resulted in the following equation:

$$
\% \Delta E B I T_{i t}=\beta_{1}\left(\% \Delta R_{i t}\right)+\alpha_{i}+v_{i t}
$$

where:

$i=1 \ldots N$

$t=1 \ldots T$;

$\% \triangle E B I T_{i t}$ - yearly percentage change of operating profit $(E B I T)$ of firm $i$;

$\% \Delta R_{i t}$ - yearly percentage change of operating revenue $(R)$ of firm $i$;

$\beta_{1}$ - estimated parameter of DOL;

$\alpha_{i}$ - unknown intercept for each entity ( $N$ firm-specific intercepts);

$v_{i t}$ - disturbance term.

After the estimations were made two more tests were applied. Firstly, the Baum test (2000), which calculates a modified Wald statistic for groupwise heteroskedasticity in the residuals following Greene (2000) in order to verify if errors are homoskedastic. ${ }^{4}$ Secondly, that written by Drukker (2003) Stata program using Wooldridge test for autocorrelation in panel data models was applied (Wooldridge, 2002, pp. 282-283) in order to verify if there is no autocorrelation in errors.

\section{Database, variables and statistics}

For the purpose of this research annual data on 851 listed companies over the period 2006-2015 were obtained from the Amadeus database (Bureau van Dijk, 2016). Data on operating revenue $(R)$ and on operating profit $(E B I T)$ was extracted. In order to calculate DOL according to the formula (1) the yearly percentage changes of operating revenue $(R)$ and operating profit $(E B I T)$ were calculated by means of data converted to natural logarithms. Observations for which there was a positive change in one variable and negative change in the other variable were eliminated. Moreover observations for which, percentage change (in absolute values) of operating revenue was higher than percentage change of operating profit were also eliminated. The authors are aware that the elimination of such observations can influence the results obtained, however the inclusion of observations, which are in contradiction to the theory can bring severe problems with the interpretation as the DOL only contains an interpretation value if DOL is positive and larger than 1.

After all exclusions an unbalanced panel with 1,670 firm-year observations (576 firms) was compiled. In order to test changes of DOL during and after

\footnotetext{
${ }^{4}$ This test can be conducted only after estimation of equation (4), which is fixed effects model.
} 
crisis period in different industries the sample was divided into five groups based on two-digit NACE Rev. 2 codes that identify industry classification. Five broad industries were defined: Manufacturing (NACE Rev. 2 code from 05 to 33), EGW (Electricity, Gas and Water Supply, NACE Rev. 2 code form 35 to 38), Construction (NACE Rev. 2 code form 41 to 43), Trade (NACE Rev. 2 code form 45 to 47) and Other services (NACE Rev. 2 code form 49 to 96). One more correction was made to the final database. Companies from Other services industry for which the four-digit NACE code was 6420 , which are the activities of holding companies were excluded. This was performed to avoid a fuzzy demarcation between industries. After all adjustments an unbalanced panel with 1,627 firm-year observations was achieved (554 firms).

Table 1 shows the number of observations (column 3), number of firms (column 4), mean value for change of operating revenue/R (column 5), standard

Table 1. Descriptive statistics for Polish stock companies by industry and subperiods

\begin{tabular}{|c|c|c|c|c|c|c|c|}
\hline Industry & Period & $\begin{array}{c}\text { no. of } \\
\text { obs. }\end{array}$ & $\begin{array}{l}\text { no. of } \\
\text { firms }\end{array}$ & $\begin{array}{l}\text { mean } \\
\% \Delta R\end{array}$ & $\begin{array}{l}\text { s.d. } \\
\% \Delta R\end{array}$ & $\begin{array}{c}\text { mean } \\
\% \Delta \mathrm{EBIT}\end{array}$ & $\begin{array}{c}\text { s.d. } \\
\% \Delta \text { EBIT }\end{array}$ \\
\hline \multirow{3}{*}{ Entire sample } & 2007-2015 & 1,627 & 554 & 0.131 & 0.412 & 0.268 & 1.139 \\
\hline & $2007-2010$ & 539 & 296 & 0.158 & 0.367 & 0.315 & 1.117 \\
\hline & 2011-2015 & 1,088 & 509 & 0.117 & 0.431 & 0.244 & 1.149 \\
\hline \multirow{3}{*}{ Manufacturing } & 2007-2015 & 509 & 151 & 0.094 & 0.319 & 0.214 & 0.985 \\
\hline & $2007-2010$ & 187 & 101 & 0.082 & 0.249 & 0.177 & 1.029 \\
\hline & 2011-2015 & 322 & 140 & 0.102 & 0.353 & 0.236 & 0.960 \\
\hline \multirow{3}{*}{ EGW } & 2007-2015 & 62 & 17 & 0.112 & 0.420 & 0.216 & 1.218 \\
\hline & $2007-2010$ & 28 & 11 & 0.120 & 0.311 & 0.384 & 1.155 \\
\hline & 2011-2015 & 34 & 15 & 0.105 & 0.497 & 0.078 & 1.267 \\
\hline \multirow{3}{*}{ Construction } & 2007-2015 & 181 & 54 & 0.122 & 0.421 & 0.198 & 1.010 \\
\hline & 2007-2010 & 73 & 36 & 0.192 & 0.376 & 0.342 & 0.906 \\
\hline & 2011-2015 & 108 & 49 & 0.075 & 0.445 & 0.100 & 1.067 \\
\hline \multirow{3}{*}{ Trade } & 2007-2015 & 266 & 91 & 0.110 & 0.505 & 0.195 & 1.066 \\
\hline & $2007-2010$ & 92 & 51 & 0.149 & 0.304 & 0.192 & 0.941 \\
\hline & 2011-2015 & 174 & 83 & 0.090 & 0.584 & 0.197 & 1.129 \\
\hline \multirow{3}{*}{ Other services } & 2007-2015 & 609 & 241 & 0.175 & 0.429 & 0.371 & 1.301 \\
\hline & $2007-2010$ & 159 & 97 & 0.246 & 0.487 & 0.526 & 1.346 \\
\hline & 2011-2015 & 450 & 222 & 0.150 & 0.404 & 0.316 & 1.282 \\
\hline
\end{tabular}

Source: own calculations. 
deviation for $\mathrm{R}$ (column 6), mean value for change of operating profit/EBIT (column 7) and standard deviation for EBIT (column 8). Based on the entire sample of companies it is worth mentioning that the number of operating companies during the post-crisis period was significantly higher than in the crisis period. The number of observations more than doubled. Surprisingly, the average increase of EBIT was higher in the crisis period compared to the post-crisis period and also to the entire research period. At the same time the standard deviation was lower during this period which means that selected companies were characterized by smaller differences in the growth rate of EBIT. A lower growth of EBIT and higher differences were observed during the post-crisis period. It is surprising because the theory predicts that shortly after the impulse (shock) in the economy, which certainly was the case during the Financial Crisis in 2008/2009, different reactions should be observed among companies. In the case of the operating revenue growth rate a similar pattern of behaviour was observed. Companies had, on average, a higher growth rate of $\mathrm{R}$ and also a lower standard deviation during the crisis period when compared with the post-crisis period as well as with the entire research period. It is worth noting that the relative differences (measured by the coefficient of variation) in growth rates of EBITs were definitely higher than the differences in growth rates of operating revenues.

In all industries the number of firms and observations was higher in the postcrisis period than in the crisis period. It means that the sample analyzed covers new entrants to the industry, however there are also several cases of those leaving. This means that the final results are not subject to a survivorship bias.

Generally the annual growth rate of operating revenue was higher during the crisis period compared to the post-crisis period at the industry level, with only one exception, which was Manufacturing. In that case firms were characterized by a higher growth rate of operating revenue in the post-crisis period. In the case of differences in growth rates of operating revenue between companies within the same industry a common pattern was observed. In all industries relative differences (measured by the coefficient of variation) in operating revenue growth rates were significantly higher during the post-crisis period than during the crisis period, which is consistent with the observation when considering the entire sample.

In the case of the annual EBIT growth rate there were more differences observed at industry level. Generally the higher growth rates were observed during the crisis period with two exceptions. Again in Manufacturing the observations are the opposite and also in Trade the behaviour of companies was different, however in the case of Trade one can conclude that the growth rate of EBIT was rather stable in the selected subperiods. Relative differences in annual growth rates of EBIT (measured by the coefficient of variation) within industries were consistent in all cases except for Manufacturing with the observation when considering the entire sample. Relative differences were sig- 
nificantly higher during the post-crisis period than in the crisis period, which is consistent with the differences observed in the annual growth rate of operating revenue. This means that during the post-crisis period companies were more differentiated both in terms of operating revenue growth and in terms of operating profit growth rate.

The analysis based on selected industries revealed further differences in terms of annual growth rate of operating revenue. Companies from all industries, except for Other services were characterized by a lower growth rate than the one observed at the aggregated level. This means that companies from Other services influenced the picture of the entire research sample. In the case of the annual growth rate of operating profit there was no common pattern and results from different industries and results between subperiods are rather mixed.

\section{Results}

Table 2 shows selected estimates of DOL for Polish listed companies for three periods: the entire research period (2007-2015), the crisis period (2007-2010) and the post-crisis period (2011-2015) using three different methods of estimation: a pooled OLS model (no individual effects), a random effects model and a fixed effects model. ${ }^{5}$ Moreover Table 2 contains estimates for the entire sample of companies and is also broken down by industries (Column 1). Column 2 shows the period for which the equation (3) was estimated. Columns 3 and 4 report estimates using the pooled OLS model (equation (4)), Columns 5 and 6 report estimates using the random effects model (equation (5)), Columns 7 and 8 report estimates using the fixed effects model (equation (6)). Afterwards the Modified Wald test for groupwise heteroskedasticity in the residuals was used following Greene (2000, p. 598) and by using the Stata module written by Baum (2000). In the case of all the estimated equations the null hypothesis was rejected which states that errors are homoskedastic. Knowing that estimators, which are robust to heteroskedastic errors were used. Additionally the Wooldridge test for autocorrelation in panel data models was run (Wooldridge, 2002, pp. 282-283) and it was found that in case of Construction and Trade during the crisis there was no evidence to reject the null hypothesis of no serial autocorrelation ${ }^{6}$. In order to have comparable outcomes for every industry and every period estimators, which are robust to heteroskedsticity and serial correlation of error terms, were used in all cases.

Before one can proceed to interpretation of the results it should be clearly stated that although the results obtained by three different estimators are pre-

\footnotetext{
${ }^{5}$ Full statistics are available in the statistical appendix in Table A4, A5, A6, A7, A8 and Table A9.

${ }^{6}$ Wooldridge test for autocorrelation results are available in statistical appendix in Table A3.
} 
sented it is suggested, based on the results of the two tests employed, that the results based on a pooled OLS estimator are the most conclusive. The Hausman test, which compares the random and fixed effects estimations, showed that at the $5 \%$ significance level only in the case of EGW industry for the entire period and the case of Trade industry (for all periods) the null hypothesis should be rejected and the fixed effects estimator used. ${ }^{7}$ This could suggest that in the majority of cases the random effects model should be used. However the Breusch-Pagan LM test showed that at the 5\% significance level only in case of the entire sample (aggregated level) for the crisis and post-crisis periods there are significant in-

Table 2. Estimation results of DOL for Polish stock companies by industry and period

\begin{tabular}{|c|c|c|c|c|c|c|c|}
\hline \multirow{2}{*}{ Industry } & \multirow{2}{*}{ Period } & \multicolumn{2}{|c|}{ POOLED OLS } & \multicolumn{2}{|c|}{$\begin{array}{l}\text { RANDOM } \\
\text { EFFECTS }\end{array}$} & \multicolumn{2}{|c|}{$\begin{array}{l}\text { FIXED } \\
\text { EFFECTS }\end{array}$} \\
\hline & & $\beta 1$ & $\begin{array}{c}\text { constant } \\
\text { term }\end{array}$ & $\beta 1$ & $\begin{array}{c}\text { constant } \\
\text { term }\end{array}$ & $\beta 1$ & $\begin{array}{c}\text { constant } \\
\text { term }\end{array}$ \\
\hline \multirow{3}{*}{$\begin{array}{l}\text { Entire } \\
\text { sample }\end{array}$} & $2007-2015$ & $1.888^{\star}$ & 0.021 & $1.888^{*}$ & 0.021 & $1.914^{\star}$ & 0.017 \\
\hline & $2007-2010$ & $2.128^{\star}$ & -0.022 & $2.131^{\star}$ & -0.022 & $2.334^{\star}$ & -0.055 \\
\hline & 2011-2015 & $1.802^{\star}$ & 0.033 & $1.807^{\star}$ & 0.033 & $1.762^{\star}$ & 0.037 \\
\hline \multirow{3}{*}{$\begin{array}{l}\text { Manufac- } \\
\text { turing }\end{array}$} & 2007-2015 & $1.939^{*}$ & 0.031 & $1.939^{\star}$ & 0.031 & $2.002^{\star}$ & 0.025 \\
\hline & $2007-2010$ & $2.688^{\star}$ & -0.043 & $2.688^{\star}$ & -0.043 & $3.167^{\star}$ & $-0.082^{\star \star}$ \\
\hline & 2011-2015 & $1.722^{\star}$ & 0.061 & $1.727^{\star}$ & 0.061 & $1.676^{*}$ & 0.065 \\
\hline \multirow{3}{*}{ EGW } & $2007-2015$ & $2.437^{\star}$ & -0.056 & $2.437^{\star}$ & -0.069 & $2.625^{\star}$ & $-0.077^{\star}$ \\
\hline & $2007-2010$ & $3.142^{\star}$ & 0.007 & $3.142^{*}$ & 0.007 & $3.261^{\star}$ & -0.007 \\
\hline & 2011-2015 & $2.204^{\star}$ & -0.153 & $2.204^{\star}$ & -0.153 & $2.318^{\star}$ & $-0.165^{\star}$ \\
\hline \multirow{3}{*}{$\begin{array}{l}\text { Construc- } \\
\text { tion }\end{array}$} & $2007-2015$ & $2.000^{*}$ & -0.046 & $2.000^{*}$ & -0.046 & $2.052^{*}$ & $-0.053^{\star}$ \\
\hline & $2007-2010$ & $1.969^{*}$ & -0.037 & $1.984^{\star}$ & -0.037 & $1.967^{\star}$ & -0.036 \\
\hline & 2011-2015 & $2.013^{*}$ & -0.050 & $2.013^{*}$ & -0.050 & $2.034^{\star}$ & $-0.052^{\star}$ \\
\hline \multirow{3}{*}{ Trade } & 2007-2015 & $1.425^{\star}$ & 0.038 & $1.413^{\star}$ & 0.054 & $1.356^{\star}$ & $0.045^{\star * *}$ \\
\hline & 2007-2010 & $2.228^{\star}$ & -0.139 & $2.139^{*}$ & -0.124 & $1.689^{*}$ & -0.059 \\
\hline & 2011-2015 & $1.317^{\star}$ & 0.078 & $1.255^{\star}$ & 0.076 & $1.215^{\star}$ & $0.087^{\star}$ \\
\hline \multirow{3}{*}{$\begin{array}{l}\text { Other } \\
\text { services }\end{array}$} & 2007-2015 & $2.055^{\star}$ & 0.011 & $2.055^{\star}$ & 0.011 & $2.145^{\star}$ & -0.005 \\
\hline & $2007-2010$ & $1.912^{\star}$ & 0.055 & $1.912^{*}$ & 0.055 & $2.275^{\star}$ & -0.034 \\
\hline & 2011-2015 & $2.126^{*}$ & -0.004 & $2.126^{*}$ & -0.004 & $2.213^{*}$ & -0.017 \\
\hline
\end{tabular}

Notes: ${ }^{\star} 1$-percent level significance; ${ }^{\star *} 5$-percent significance level; ${ }^{\star * \star} 10$-percent significance level.

\footnotetext{
${ }^{7}$ Full statistics are available in the statistical appendix in Table A1.
} 
dividual effects. ${ }^{8}$ In the rest of the cases estimations that were received based on the pooled OLS and random effects model are the same. Based on the above the is no one-size-fits-all estimator and being aware of all the drawbacks and limitations it is suggested that the pooled OLS estimations are the most conclusive.

At the very beginning it should be mentioned that both at the aggregated and industry level statistically significant parameters in all periods for DOL were found regardless of the estimator that was used. Additionally it was checked as to whether the differences in the estimated DOL level obtained between periods for each industry are significant. In order to test the differences in the levels of the estimated DOL a two-sample t-test for the difference between means based on pooled OLS estimations was employed. ${ }^{9}$ Only in the case of Construction DOL levels between selected periods are not significantly different. In the rest of the cases estimated DOL levels are significantly different when comparing the entire period vs the crisis period, the entire period vs the post-crisis period and the crisis period vs the post-crisis period. Finally it was checked as to whether the estimated DOL levels for industries (for the entire period) are significantly different. Again, a two-sample t-test for the difference between means based on pooled OLS estimations for the entire period was employed. ${ }^{10}$ Based on the results of this test it should be noted that in all cases the differences in DOL levels are different at the $5 \%$ significance level.

Disaggregation to the industry level revealed significant differences in the DOL level between companies from different industries. Firms from all industries, except for Trade, had higher levels of DOL in the entire period researched compared to the results, which can be observed at the aggregated level. Comparing DOL levels for the entire period analyzed between industries it was found that the highest level of DOL was observed in the EGW industry, whilst the lowest in was observed in Trade industry.

Regardless of the estimator used it was found that at the aggregated level during the crisis period the level of DOL was higher than during the post-crisis period and also during the entire research period. This means that Polish stock companies were characterized by the highest DOL level during the crisis and by the lowest DOL level during the post-crisis period. The same pattern was observed in all industries, except for Construction and Other services. In the case of the Construction industry differences (as mentioned before) are not significant, whilst in the case of Other services there was an increase of DOL. The sharpest change was observed in Manufacturing, EGW and Trade. In all these cases a decline in DOL level was observed. In case of Construction there was no evidence of significant change, whilst in Other services the change was very small, but positive.

\footnotetext{
${ }^{8}$ Full statistics are available in the statistical appendix in Table A2.

${ }^{9}$ Full statistics are available in the statistical appendix in Table A10.

${ }^{10}$ Full statistics are available in the statistical appendix in Table A11.
} 


\section{Conclusions}

According to the theory, the higher level of operating risk in the crisis period comes from falling operating profits with constant fixed costs in the short run. After the crisis the DOL level is expected to decrease due to at least two factors. First, EBITs tend to rise. Second, fixed costs may be reduced and adjusted to the diminished level of operating activity (formula (2)). This relationship leads to the first hypothesis: $\mathrm{H}_{1}$ - operating risk measured by the degree of operating leverage is higher within the period of economic crisis than in the post-crisis period. The results of the panel data model estimation support this hypothesis with statistical significance at the aggregated level.

For almost all industries the response to the Financial Crisis was similar. With the exception of Other services and Construction, for all industries the DOL was higher in the period 2007-2010 compared to the post-crisis period (2011-2015). This result supports $H_{1}$ at the industry level. In case of Construction the phenomenon of no significant change in the DOL level could arise from the fact that some major constructions companies fell into trouble because contracts for the construction of highways and stadiums before EURO 2012 were terminated with a loss. The case of Other services, for which DOL increased after the crisis period, does not support $\mathrm{H}_{1}$. The possible reason for this distortion was the dramatic increase of the number of observations and number of companies in the post-crisis period. In the post-crisis period the number of companies doubled and the number of observations tripled. Taking the above into account and also the wide range of activities within Other services the unexpected increase of DOL in the post-crisis period was caused by the structural change of the subsample.

Some expected differences between industries were identified. For example, DOL for Trade industry was significantly lower than for other industries, which is exactly what the theory predicts. Unfortunately it is not possible to state the same in the cases of comparisons between Manufacturing - Construction industry and Manufacturing - Other services. The higher value of DOL for the Manufacturing industry supports $\mathrm{H}_{2}$ only in one of three cases. The stronger support for the $\mathrm{H}_{2}$ hypothesis comes from the EGW supply industry. Companies within this industry had a higher level of DOL than in Trade, Construction and Other services. The industry with the highest share of fixed operating costs suffers the highest level of operating risk, which strongly supports $\mathrm{H}_{2}$.

Apart from the theoretical significance of this particular study, such research may be interesting from the investors' point of view. It may help investors in the decision making process as to the moment of investment and the industry in which they invest. Not only the expected rate of return, but also expected level of operating risk for entire period, as well as for the subperiods should be taken into account. 


\section{Statistical appendix}

Table A1. Hausman's specification test of individual effects

\begin{tabular}{|c|c|c|c|c|c|c|}
\hline Period & $\begin{array}{c}\text { Entire } \\
\text { sample }\end{array}$ & $\begin{array}{c}\text { Manu- } \\
\text { facturing }\end{array}$ & EGW & $\begin{array}{c}\text { Construc- } \\
\text { tion }\end{array}$ & Trade & $\begin{array}{c}\text { Other } \\
\text { services }\end{array}$ \\
\hline \multirow{2}{*}{$2007-2015$} & 0.69 & 1.06 & 5.01 & 1.72 & 3.96 & 1.59 \\
& $(0.4076)$ & $(0.3026)$ & $(0.0253)$ & $(0.1902)$ & $(0.0467)$ & $(0.2075)$ \\
\hline \multirow{2}{*}{$2007-2010$} & 2.95 & 2.4 & 1.06 & 0.05 & 6.62 & 1.95 \\
& $(0.0858)$ & $(0.1215)$ & $(0.3043)$ & $(0.8286)$ & $(0.0101)$ & $(0.1631)$ \\
\hline \multirow{2}{*}{$2011-2015$} & 1.00 & 0.46 & 1.00 & 0.10 & 2.99 & 0.51 \\
& $(0.3178)$ & $(0.4974)$ & $(0.3167)$ & $(0.7510)$ & $(0.0837)$ & $(0.4755)$ \\
\hline
\end{tabular}

$\mathrm{H}_{0}$ : random-effects estimator is efficient and consistent estimator of the true parameters. $p$-value in parenthesis.

Table A2. Breusch and Pagan Lagrangian multiplier test for random effects

\begin{tabular}{|c|c|c|c|c|c|c|}
\hline Period & $\begin{array}{c}\text { Entire } \\
\text { sample }\end{array}$ & $\begin{array}{c}\text { Manu- } \\
\text { facturing }\end{array}$ & EGW & $\begin{array}{c}\text { Construc- } \\
\text { tion }\end{array}$ & Trade & $\begin{array}{c}\text { Other } \\
\text { services }\end{array}$ \\
\hline \multirow{2}{*}{$2007-2015$} & 0.00 & 0.00 & 0.00 & 0.00 & 1.65 & 0.00 \\
& $(1.0000)$ & $(1.0000)$ & $(1.0000)$ & $(1.0000)$ & $(0.0997)$ & $(1.0000)$ \\
\hline \multirow{2}{*}{$2007-2010$} & 13.51 & 0.00 & 0.00 & 0.67 & 2.66 & 0.00 \\
& $(0.0001)$ & $(1.0000)$ & $(1.0000)$ & $(0.2060)$ & $(0.0514)$ & $(1.0000)$ \\
\hline \multirow{2}{*}{$2011-2015$} & 18.29 & 1.33 & 0.00 & 0.00 & 0.02 & 0.00 \\
& $(0.0000)$ & $(0.1241)$ & $(1.0000)$ & $(1.0000)$ & $(0.4424)$ & $(1.0000)$ \\
\hline
\end{tabular}

$\mathrm{H}_{0}$ : variances across entities is zero (no significant difference across units, i.e. no panel effect). $p$-value in parenthesis.

Table A3. Wooldridge test for autocorrelation in panel data

\begin{tabular}{|c|c|c|c|c|c|c|}
\hline Period & $\begin{array}{c}\text { Entire } \\
\text { sample }\end{array}$ & $\begin{array}{c}\text { Manu- } \\
\text { facturing }\end{array}$ & EGW & $\begin{array}{c}\text { Construc- } \\
\text { tion }\end{array}$ & Trade & $\begin{array}{c}\text { Other } \\
\text { services }\end{array}$ \\
\hline \multirow{2}{*}{$2007-2015$} & 1.368 & 0.842 & 0.662 & 1.979 & 0.473 & 0.631 \\
& $(0.2439)$ & $(0.3629)$ & $(0.4347)$ & $(0.1786)$ & $(0.4979)$ & $(0.4306)$ \\
\hline \multirow{2}{*}{$2007-2010$} & 0.035 & 2.562 & 0.412 & 12.660 & 14.665 & 0.650 \\
& $(0.8536)$ & $(0.1303)$ & $(0.5559)$ & $(0.0162)$ & $(0.0087)$ & $(0.4653)$ \\
\hline \multirow{2}{*}{$2011-2015$} & 1.357 & 0.135 & 0.024 & 0.309 & 1.035 & 0.985 \\
& $(0.2464)$ & $(0.7155)$ & $(0.8838)$ & $(0.5896)$ & $(0.3225)$ & $(0.3271)$ \\
\hline
\end{tabular}

$\mathrm{H}_{0}$ : no serial autocorrelation.

$p$-value in parenthesis. 
Table A4. Full estimation results of DOL for Polish stock companies by period in the Entire sample, Manufacturing and EGW - pooled OLS estimator

\begin{tabular}{|l|c|c|c|c|c|c|c|c|c|}
\hline \multicolumn{1}{|c|}{ Industry } & \multicolumn{2}{|c|}{ Entire sample } & \multicolumn{2}{c|}{ Manufacturing } & \multicolumn{3}{c|}{ EGW } \\
\hline Period & $\begin{array}{l}2007- \\
-2015\end{array}$ & $\begin{array}{c}2007- \\
-2010\end{array}$ & $\begin{array}{c}2011- \\
-2015\end{array}$ & $\begin{array}{c}2007- \\
-2015\end{array}$ & $\begin{array}{c}2007- \\
-2010\end{array}$ & $\begin{array}{c}2010- \\
-2015\end{array}$ & $\begin{array}{c}2007- \\
-2015\end{array}$ & $\begin{array}{c}2007- \\
-2010\end{array}$ & $\begin{array}{c}2010- \\
-2015\end{array}$ \\
\hline$\beta 1$ & 1.888 & 2.128 & 1.802 & 1.939 & 2.688 & 1.722 & 2.437 & 3.142 & 2.204 \\
\hline s.e. & 0.175 & 0.2 & 0.207 & 0.383 & 0.302 & 0.389 & 0.217 & 0.481 & 0.131 \\
\hline $\begin{array}{l}\text { constant } \\
\text { term }\end{array}$ & 0.021 & -0.022 & 0.033 & 0.031 & -0.043 & 0.061 & -0.056 & 0.007 & -0.153 \\
\hline s.e. & 0.03 & 0.04 & 0.035 & 0.038 & 0.051 & 0.048 & 0.08 & 0.133 & 0.096 \\
\hline $\mathrm{R}^{2}$ & 0.4661 & 0.4901 & 0.4581 & 0.3935 & 0.4231 & 0.4014 & 0.7065 & 0.7141 & 0.7471 \\
\hline $\mathrm{R}^{2}$ overall & n.a. & n.a. & n.a. & n.a. & n.a. & n.a. & n.a. & n.a. & n.a. \\
\hline $\mathrm{R}^{2}$ between & n.a. & n.a. & n.a. & n.a. & n.a. & n.a. & n.a. & n.a. & n.a. \\
\hline $\mathrm{R}^{2}$ within & n.a. & n.a. & n.a. & n.a. & n.a. & n.a. & n.a. & n.a. & n.a. \\
\hline sigma_u & n.a. & n.a. & n.a. & n.a. & n.a. & n.a. & n.a. & n.a. & n.a. \\
\hline sigma_e & n.a. & n.a. & n.a. & n.a. & n.a. & n.a. & n.a. & n.a. & n.a. \\
\hline rho & n.a. & n.a. & n.a. & n.a. & n.a. & n.a. & n.a. & n.a. & n.a. \\
\hline corr (ui, Xb) & n.a. & n.a. & n.a. & n.a. & n.a. & n.a. & n.a. & n.a. & n.a. \\
\hline F statistic & 115.9 & 113.7 & 76 & 25.56 & 79.16 & 19.64 & 126.6 & 42.61 & 281 \\
\hline$p$-value & 0 & 0 & 0 & 0 & 0 & 0 & 0 & 0 & 0 \\
\hline no. of obs. & 1,627 & 539 & 1,088 & 509 & 187 & 322 & 62 & 28 & 34 \\
\hline no. of firms & n.a. & n.a. & n.a. & n.a. & n.a. & n.a. & n.a. & n.a. & n.a. \\
\hline
\end{tabular}

Notes: s.e. - standard error; rho - interclass correlation; corr (ui, $\mathrm{Xb}$ ) - correlation between errors and regressors; sigma_u - sd of residuals within groups ui; sigma_e - sd of residuals (overall error term); ui - error term within group. 
Table A5. Full estimation results of DOL for Polish stock companies by period in Construction, Trade and Other services - pooled OLS estimator

\begin{tabular}{|l|c|c|c|c|c|c|c|c|c|}
\hline \multicolumn{1}{|c|}{ Industry } & \multicolumn{2}{|c|}{ Construction } & \multicolumn{3}{c|}{ Trade } & \multicolumn{3}{c|}{ Other services } \\
\hline Period & $2007-$ & $2007-$ & $2011-$ & $2007-$ & $2007-$ & $2010-$ & $2007-$ & $2007-$ & $2010-$ \\
-2015 & -2010 & -2015 & -2015 & -2010 & -2015 & -2015 & -2010 & -2015 \\
\hline$\beta 1$ & 2.000 & 1.969 & 2.013 & 1.425 & 2.228 & 1.317 & 2.055 & 1.912 & 2.126 \\
\hline s.e. & 0.132 & 0.102 & 0.189 & 0.290 & 0.313 & 0.239 & 0.179 & 0.278 & 0.164 \\
\hline $\begin{array}{l}\text { constant } \\
\text { term }\end{array}$ & -0.046 & -0.037 & -0.050 & 0.038 & -0.139 & 0.078 & 0.011 & 0.055 & -0.004 \\
\hline s.e. & 0.042 & 0.060 & 0.056 & 0.061 & 0.079 & 0.071 & 0.040 & 0.089 & 0.042 \\
\hline $\mathrm{R}^{2}$ & 0.6955 & 0.6669 & 0.7032 & 0.4561 & 0.5175 & 0.4635 & 0.4582 & 0.4782 & 0.4482 \\
\hline $\mathrm{R}^{2}$ overall & n.a. & n.a. & n.a. & n.a. & n.a. & n.a. & n.a. & n.a. & n.a. \\
\hline $\mathrm{R}^{2}$ between & n.a. & n.a. & n.a. & n.a. & n.a. & n.a. & n.a. & n.a. & n.a. \\
\hline $\mathrm{R}^{2}$ within & n.a. & n.a. & n.a. & n.a. & n.a. & n.a. & n.a. & n.a. & n.a. \\
\hline sigma_u & n.a. & n.a. & n.a. & n.a. & n.a. & n.a. & n.a. & n.a. & n.a. \\
\hline sigma_e & n.a. & n.a. & n.a. & n.a. & n.a. & n.a. & n.a. & n.a. & n.a. \\
\hline rho & n.a. & n.a. & n.a. & n.a. & n.a. & n.a. & n.a. & n.a. & n.a. \\
\hline corr (ui, Xb) & n.a. & n.a. & n.a. & n.a. & n.a. & n.a. & n.a. & n.a. & n.a. \\
\hline F statistic & 229.2 & 371.7 & 113.4 & 24.24 & 50.68 & 30.46 & 131.4 & 47.35 & 167.3 \\
\hline$p$-value & 0.000 & 0.000 & 0.000 & 0.000 & 0.000 & 0.000 & 0.000 & 0.000 & 0.000 \\
\hline no. of obs. & 181 & 73 & 108 & 266 & 92 & 174 & 609 & 159 & 450 \\
\hline no. of firms & n.a. & n.a. & n.a. & n.a. & n.a. & n.a. & n.a. & n.a. & n.a. \\
\hline
\end{tabular}

Notes: s.e. - standard error; rho - interclass correlation; corr (ui, $\mathrm{Xb}$ ) - correlation between errors and regressors; sigma_u - sd of residuals within groups ui; sigma_e - sd of residuals (overall error term); ui - error term within group. 
Table A6. Full estimation results of DOL for Polish stock companies by period in the Entire sample, Manufacturing and EGW - random effects estimator

\begin{tabular}{|l|c|c|c|c|c|c|c|c|c|}
\hline \multicolumn{1}{|c|}{ Industry } & \multicolumn{3}{|c|}{ Entire sample } & \multicolumn{3}{c|}{ Manufacturing } & \multicolumn{3}{c|}{ EGW } \\
\hline Period & $2007-$ & $2007-$ & $2011-$ & $2007-$ & $2007-$ & $2010-$ & $2007-$ & $2007-$ & $2010-$ \\
-2015 & -2010 & -2015 & -2015 & -2010 & -2015 & -2015 & -2010 & -2015 \\
\hline$\beta 1$ & 1.888 & 2.131 & 1.807 & 1.939 & 2.688 & 1.727 & 2.437 & 3.142 & 2.204 \\
\hline s.e. & 0.175 & 0.2 & 0.206 & 0.383 & 0.302 & 0.392 & 0.217 & 0.481 & 0.131 \\
\hline $\begin{array}{l}\text { constant } \\
\text { term }\end{array}$ & 0.021 & -0.022 & 0.033 & 0.031 & -0.043 & 0.061 & -0.056 & 0.007 & -0.153 \\
\hline s.e. & 0.030 & 0.040 & 0.036 & 0.038 & 0.051 & 0.049 & 0.080 & 0.133 & 0.096 \\
\hline $\mathrm{R}^{2}$ & n.a. & n.a. & n.a. & n.a. & n.a. & n.a. & n.a. & n.a. & n.a. \\
\hline $\mathrm{R}^{2}$ overall & 0.4661 & 0.4901 & 0.4581 & 0.3935 & 0.4231 & 0.4014 & 0.7065 & 0.7141 & 0.7471 \\
\hline $\mathrm{R}^{2}$ between & 0.4497 & 0.5011 & 0.4346 & 0.3892 & 0.4943 & 0.3403 & 0.4906 & 0.1922 & 0.5565 \\
\hline $\mathrm{R}^{2}$ within & 0.4746 & 0.4756 & 0.4702 & 0.4060 & 0.3892 & 0.4269 & 0.7587 & 0.8073 & 0.7853 \\
\hline sigma_u & 0.0000 & 0.1442 & 0.2656 & 0.0000 & 0.0000 & 0.1998 & 0.0000 & 0.0000 & 0.0000 \\
\hline sigma_e & 0.8649 & 0.8255 & 0.8585 & 0.7986 & 0.873 & 0.7476 & 0.6764 & 0.6163 & 0.7288 \\
\hline rho & 0.0000 & 0.0296 & 0.0874 & 0.0000 & 0.0000 & 0.0667 & 0.0000 & 0.0000 & 0.0000 \\
\hline corr (ui, Xb) & n.a. & n.a. & n.a. & n.a. & n.a. & n.a. & n.a. & n.a. & n.a. \\
\hline F statistic & 115.90 & 113.60 & 76.63 & 25.56 & 79.16 & 19.43 & 126.60 & 42.61 & 281.00 \\
\hline$p$-value & 0,000 & 0,000 & 0,000 & 0,000 & 0,000 & 0,000 & 0,000 & 0,000 & 0,000 \\
\hline no. of obs. & 1,627 & 539 & 1,088 & 509 & 187 & 322 & 62 & 28 & 34 \\
\hline no. of firms & 554 & 296 & 509 & 151 & 101 & 140 & 17 & 11 & 15 \\
\hline
\end{tabular}

Notes: s.e. - standard error; rho - interclass correlation; corr (ui, Xb) - correlation between errors and regressors; sigma_u - sd of residuals within groups ui; sigma_e - sd of residuals (overall error term); ui - error term within group. 
Table A7. Full estimation results of DOL for Polish stock companies by period in Construction, Trade and Other services - random effects estimator

\begin{tabular}{|l|c|c|c|c|c|c|c|c|c|}
\hline \multicolumn{1}{|c|}{ Industry } & \multicolumn{3}{|c|}{ Construction } & \multicolumn{3}{c|}{ Trade } & \multicolumn{3}{c|}{ Other services } \\
\hline Period & $\begin{array}{c}2007- \\
-2015\end{array}$ & $\begin{array}{c}2007- \\
-2010\end{array}$ & $\begin{array}{c}2011- \\
-2015\end{array}$ & $\begin{array}{c}2007- \\
-2015\end{array}$ & $\begin{array}{c}2007- \\
-2010\end{array}$ & $\begin{array}{c}2010- \\
-2015\end{array}$ & $\begin{array}{c}2007- \\
-2015\end{array}$ & $\begin{array}{c}2007- \\
-2010\end{array}$ & $\begin{array}{c}2010- \\
-2015\end{array}$ \\
\hline$\beta 1$ & 2.000 & 1.984 & 2.013 & 1.413 & 2.139 & 1.255 & 2.055 & 1.912 & 2.126 \\
\hline s.e. & 0.132 & 0.114 & 0.189 & 0.279 & 0.324 & 0.189 & 0.179 & 0.278 & 0.164 \\
\hline $\begin{array}{l}\text { constant } \\
\text { term }\end{array}$ & -0.046 & -0.037 & -0.050 & 0.054 & -0.124 & 0.076 & 0.011 & 0.055 & -0.004 \\
\hline s.e. & 0.042 & 0.073 & 0.056 & 0.071 & 0.091 & 0.102 & 0.040 & 0.089 & 0.042 \\
\hline $\mathrm{R}^{2}$ & n.a. & n.a. & n.a. & n.a. & n.a. & n.a. & n.a. & n.a. & n.a. \\
\hline $\mathrm{R}^{2}$ overall & 0.6955 & 0.6669 & 0.7032 & 0.4561 & 0.5175 & 0.4635 & 0.4582 & 0.4782 & 0.4482 \\
\hline $\mathrm{R}^{2}$ between & 0.5656 & 0.5021 & 0.5636 & 0.3446 & 0.5929 & 0.2758 & 0.4892 & 0.4939 & 0.5133 \\
\hline $\mathrm{R}^{2}$ within & 0.7295 & 0.7565 & 0.7592 & 0.5141 & 0.4589 & 0.6704 & 0.4468 & 0.4497 & 0.4023 \\
\hline sigma_u & 0.0000 & 0.3558 & 0.0000 & 0.5140 & 0.4220 & 0.8769 & 0.0000 & 0.0000 & 0.0000 \\
\hline sigma_e & 0.5839 & 0.4827 & 0.6130 & 0.7291 & 0.5810 & 0.5553 & 1.0350 & 1.0290 & 1.0370 \\
\hline rho & 0.0000 & 0.3521 & 0.0000 & 0.3319 & 0.3454 & 0.7138 & 0.0000 & 0.0000 & 0.0000 \\
\hline corr (ui, Xb) & n.a. & n.a. & n.a. & n.a. & n.a. & n.a. & n.a. & n.a. & n.a. \\
\hline F statistic & 229.20 & 304.90 & 113.40 & 25.66 & 43.65 & 43.99 & 131.40 & 47.35 & 167.30 \\
\hline$p$-value & 0.000 & 0.000 & 0.000 & 0.000 & 0.000 & 0.000 & 0.000 & 0.000 & 0.000 \\
\hline no. of obs. & 181 & 73 & 108 & 266 & 92 & 174 & 609 & 159 & 450 \\
\hline no. of firms & 54 & 36 & 49 & 91 & 51 & 83 & 241 & 97 & 222 \\
\hline
\end{tabular}

Notes: s.e. - standard error; rho - interclass correlation; corr (ui, $\mathrm{Xb}$ ) - correlation between errors and regressors; sigma_u - sd of residuals within groups ui; sigma_e - sd of residuals (overall error term); ui - error term within group. 
Table A8. Full estimation results of DOL for Polish stock companies by period in the Entire sample, Manufacturing and EGW - fixed effects estimator

\begin{tabular}{|l|c|c|c|c|c|c|c|c|c|}
\hline \multicolumn{1}{|c|}{ Industry } & \multicolumn{3}{|c|}{ Entire sample } & \multicolumn{3}{c|}{ Manufacturing } & \multicolumn{3}{c|}{ EGW } \\
\hline Period & $\begin{array}{l}2007- \\
-2015\end{array}$ & $\begin{array}{c}2007- \\
-2010\end{array}$ & $\begin{array}{c}2011- \\
-2015\end{array}$ & $\begin{array}{c}2007- \\
-2015\end{array}$ & $\begin{array}{c}2007- \\
-2010\end{array}$ & $\begin{array}{c}2010- \\
-2015\end{array}$ & $\begin{array}{c}2007-2015 \\
-2007-\end{array}$ & $\begin{array}{c}2010- \\
-2015\end{array}$ \\
\hline$\beta 1$ & 1.914 & 2.334 & 1.762 & 2.002 & 3.167 & 1.676 & 2.625 & 3.261 & 2.318 \\
\hline s.e. & 0.207 & 0.182 & 0.224 & 0.457 & 0.451 & 0.415 & 0.207 & 0.549 & 0.230 \\
\hline $\begin{array}{l}\text { constant } \\
\text { term }\end{array}$ & 0.017 & -0.055 & 0.037 & 0.025 & -0.082 & 0.065 & -0.077 & -0.007 & -0.165 \\
\hline s.e. & 0.027 & 0.029 & 0.026 & 0.043 & 0.037 & 0.042 & 0.023 & 0.066 & 0.024 \\
\hline $\mathrm{R}^{2}$ & 0.4746 & 0.4756 & 0.4702 & 0.4060 & 0.3892 & 0.4269 & 0.7587 & 0.8073 & 0.7853 \\
\hline $\mathrm{R}^{2}$ overall & 0.4661 & 0.4901 & 0.4581 & 0.3935 & 0.4231 & 0.4014 & 0.7065 & 0.7141 & 0.7471 \\
\hline $\mathrm{R}^{2}$ between & 0.4497 & 0.5011 & 0.4346 & 0.3892 & 0.4943 & 0.3403 & 0.4906 & 0.1922 & 0.5565 \\
\hline $\mathrm{R}^{2}$ within & 0.4746 & 0.4756 & 0.4702 & 0.4060 & 0.3892 & 0.4269 & 0.7587 & 0.8073 & 0.7853 \\
\hline sigma_u & 0.5992 & 0.7061 & 0.7206 & 0.4751 & 0.6126 & 0.6026 & 0.3818 & 0.3897 & 0.3775 \\
\hline sigma_e & 0.8649 & 0.8255 & 0.8585 & 0.7986 & 0.8730 & 0.7476 & 0.6764 & 0.6163 & 0.7288 \\
\hline rho & 0.3243 & 0.4225 & 0.4133 & 0.2614 & 0.3299 & 0.3939 & 0.2417 & 0.2856 & 0.2115 \\
\hline corr (ui, Xb) & -0.0240 & -0.1302 & 0.0302 & -0.0537 & -0.2271 & 0.0338 & -0.2366 & -0.0936 & -0.1642 \\
\hline F statistic & 85.86 & 164.60 & 62.14 & 19.21 & 49.32 & 16.32 & 161.50 & 35.26 & 101.90 \\
\hline$p$-value & 0.000 & 0.000 & 0.000 & 0.000 & 0.000 & 0.000 & 0.000 & 0.000 & 0.000 \\
\hline no. of obs. & 1,627 & 539 & 1,088 & 509 & 187 & 322 & 62 & 28 & 34 \\
\hline no. of firms & 554 & 296 & 509 & 151 & 101 & 140 & 17 & 11 & 15 \\
\hline
\end{tabular}

Notes: s.e. - standard error; rho - interclass correlation; corr (ui, $\mathrm{Xb}$ ) - correlation between errors and regressors; sigma_u - sd of residuals within groups ui; sigma_e - sd of residuals (overall error term); ui - error term within group 
Table A9. Full estimation results of DOL for Polish stock companies by period in Construction, Trade and Other services - fixed effects estimator

\begin{tabular}{|l|c|c|c|c|c|c|c|c|c|}
\hline \multicolumn{1}{|c|}{ Industry } & \multicolumn{3}{|c|}{ Construction } & \multicolumn{3}{c|}{ Trade } & \multicolumn{3}{c|}{ Other services } \\
\hline Period & $\begin{array}{l}2007- \\
-2015\end{array}$ & $\begin{array}{c}2007- \\
-2010\end{array}$ & $\begin{array}{c}2011- \\
-2015\end{array}$ & $\begin{array}{c}2007- \\
-2015\end{array}$ & $\begin{array}{c}2007- \\
-2010\end{array}$ & $\begin{array}{c}2010- \\
-2015\end{array}$ & $\begin{array}{c}2007- \\
-2015\end{array}$ & $\begin{array}{c}2007- \\
-2010\end{array}$ & $\begin{array}{c}2010- \\
-2015\end{array}$ \\
\hline$\beta 1$ & 2.052 & 1.967 & 2.034 & 1.356 & 1.689 & 1.215 & 2.145 & 2.275 & 2.213 \\
\hline s.e. & 0.158 & 0.142 & 0.231 & 0.244 & 0.255 & 0.159 & 0.266 & 0.332 & 0.212 \\
\hline $\begin{array}{l}\text { constant } \\
\text { term }\end{array}$ & -0.053 & -0.036 & -0.052 & 0.045 & -0.059 & 0.087 & -0.005 & -0.034 & -0.017 \\
\hline s.e. & 0.019 & 0.027 & 0.017 & 0.027 & 0.038 & 0.014 & 0.047 & 0.082 & 0.032 \\
\hline $\mathrm{R}^{2}$ & 0.7295 & 0.7565 & 0.7592 & 0.5141 & 0.4589 & 0.6704 & 0.4468 & 0.4497 & 0.4023 \\
\hline $\mathrm{R}^{2}$ overall & 0.6955 & 0.6669 & 0.7032 & 0.4561 & 0.5175 & 0.4635 & 0.4582 & 0.4782 & 0.4482 \\
\hline $\mathrm{R}^{2}$ between & 0.5656 & 0.5021 & 0.5636 & 0.3446 & 0.5929 & 0.2758 & 0.4892 & 0.4939 & 0.5133 \\
\hline $\mathrm{R}^{2}$ within & 0.7295 & 0.7565 & 0.7592 & 0.5141 & 0.4589 & 0.6704 & 0.4468 & 0.4497 & 0.4023 \\
\hline sigma_u & 0.3223 & 0.5159 & 0.4345 & 0.7462 & 0.7183 & 0.9940 & 0.6860 & 0.9017 & 0.7461 \\
\hline sigma_e & 0.5839 & 0.4827 & 0.6130 & 0.7291 & 0.5810 & 0.5553 & 1.0350 & 1.0290 & 1.0370 \\
\hline rho & 0.2336 & 0.5332 & 0.3345 & 0.5115 & 0.6045 & 0.7622 & 0.3054 & 0.4342 & 0.3411 \\
\hline corr (ui, Xb) & -0.0811 & 0.0024 & -0.0255 & 0.0670 & 0.2961 & 0.0813 & -0.0739 & -0.2348 & -0.0578 \\
\hline F statistic & 168.20 & 192.60 & 77.57 & 30.88 & 43.74 & 58.49 & 65.10 & 46.95 & 108.40 \\
\hline$p$-value & 0.000 & 0.000 & 0.000 & 0.000 & 0.000 & 0.000 & 0.000 & 0.000 & 0.000 \\
\hline no. of obs. & 181 & 73 & 108 & 266 & 92 & 174 & 609 & 159 & 450 \\
\hline no. of firms & 54 & 36 & 49 & 91 & 51 & 83 & 241 & 97 & 222 \\
\hline
\end{tabular}

Notes: s.e. - standard error; rho - interclass correlation; corr (ui, $\mathrm{Xb}$ ) - correlation between errors and regressors; sigma_u - sd of residuals within groups ui; sigma_e - sd of residuals (overall error term); ui - error term within group 
Table A10. Results for two-sample $t$-test for difference between means based on pooled OLS estimations for selected periods, by industry

\begin{tabular}{|c|c|c|c|}
\hline Industry & $\begin{array}{l}\text { Entire period vs crisis } \\
\text { period }\end{array}$ & $\begin{array}{l}\text { Entire period vs post- } \\
\text {-crisis period }\end{array}$ & $\begin{array}{l}\text { Crisis period vs post } \\
\text {-crisis period }\end{array}$ \\
\hline $\begin{array}{l}\text { Entire } \\
\text { sample }\end{array}$ & $\begin{array}{c}\text { Test statistics: } \\
t(827)=-24.882 \\
\text { Two-tail test } \\
p \text {-value }=0.000 \\
(\text { One-tail test } \\
p \text {-value }=0.000)\end{array}$ & $\begin{array}{c}\text { Test statistics: } \\
t(2,059)=11.272 \\
\text { Two-tail test } \\
p \text {-value }=0.000 \\
\text { (One-tail test } \\
p \text {-value }=0.000)\end{array}$ & $\begin{array}{c}\text { Test statistics: } \\
t(1,106)=30.587 \\
\text { Two-tail test } \\
p \text {-value }=0.000 \\
\text { (One-tail test } \\
p \text {-value }=0.000)\end{array}$ \\
\hline $\begin{array}{l}\text { Manufac- } \\
\text { turing }\end{array}$ & $\begin{array}{c}\text { Test statistics: } \\
t(417)=-26.889 \\
\text { Two-tail test } \\
p \text {-value }=0.000 \\
\text { (One-tail test } \\
p \text {-value }=0.000)\end{array}$ & $\begin{array}{c}\text { Test statistics: } \\
t(675)=7.881 \\
\text { Two-tail test } \\
p \text {-value }=0.000 \\
\text { (One-tail test } \\
p \text {-value }=0.000)\end{array}$ & $\begin{array}{c}\text { Test statistics: } \\
t(466)=31.216 \\
\text { Two-tail test } \\
p \text {-value }=0.000 \\
(\text { One-tail test } \\
p \text {-value }=0.000)\end{array}$ \\
\hline EGW & $\begin{array}{c}\text { Test statistics: } \\
t(32)=-7.422 \\
\text { Two-tail test } \\
p \text {-value }=0.000 \\
\text { (One-tail test } \\
p \text {-value }=0.000)\end{array}$ & $\begin{array}{c}\text { Test statistics: } \\
t(93)=6.553 \\
\text { Two-tail test } \\
p \text {-value }=0.000 \\
\text { (One-tail test } \\
p \text {-value }=0.000)\end{array}$ & $\begin{array}{c}\text { Test statistics: } \\
t(30)=10.018 \\
\text { Two-tail test } \\
p \text {-value }=0.000 \\
(\text { One-tail test } \\
p \text {-value }=0.000)\end{array}$ \\
\hline $\begin{array}{l}\text { Construc- } \\
\text { tion }\end{array}$ & $\begin{array}{c}\text { Test statistics: } \\
t(170)=2.006 \\
\text { Two-tail test } \\
p \text {-value }=0.046 \\
\text { (One-tail test } \\
p \text {-value }=0.023)\end{array}$ & $\begin{array}{c}\text { Test statistics: } \\
t(169)=-0.629 \\
\text { Two-tail test } \\
p \text {-value }=\mathbf{0 . 5 3 0} \\
\text { (One-tail test } \\
p \text {-value }=\mathbf{0 . 2 6 5 )}\end{array}$ & $\begin{array}{c}\text { Test statistics: } \\
t(171)=-2.023 \\
\text { Two-tail test } \\
p \text {-value }=0.045 \\
\text { (One-tail test } \\
p \text {-value }=0.022 \text { ) }\end{array}$ \\
\hline Trade & $\begin{array}{c}\text { Test statistics: } \\
t(148)=-21.608 \\
\text { Two-tail test } \\
p \text {-value }=0.000 \\
\text { (One-tail test } \\
p \text {-value }=0.000)\end{array}$ & $\begin{array}{c}\text { Test statistics: } \\
t(415)=4.254 \\
\text { Two-tail test } \\
p \text {-value }=0.000 \\
(\text { One-tail test } \\
p \text {-value }=0.000)\end{array}$ & $\begin{array}{c}\text { Test statistics: } \\
t(148)=24.407 \\
\text { Two-tail test } \\
p \text {-value }=0.000 \\
\text { (One-tail test } \\
p \text {-value }=0.000)\end{array}$ \\
\hline $\begin{array}{l}\text { Other } \\
\text { services }\end{array}$ & $\begin{array}{c}\text { Test statistics: } \\
t(193) 6.161 \\
\text { Two-tail test } \\
p \text {-value }=0.000 \\
\text { (One-tail test } \\
p \text {-value }=0.000)\end{array}$ & $\begin{array}{c}\text { Test statistics: } \\
t(1009)=-6.670 \\
\text { Two-tail test } \\
p \text {-value }=0.000 \\
\text { (One-tail test } \\
p \text {-value }=0.000)\end{array}$ & $\begin{array}{c}\text { Test statistics: } \\
t(198)=9.160 \\
\text { Two-tail test } \\
p \text {-value }=0.000 \\
\text { (One-tail test } \\
p \text {-value }=0.000)\end{array}$ \\
\hline
\end{tabular}

$\mathrm{H}_{0}$ : no difference between the two population means. 


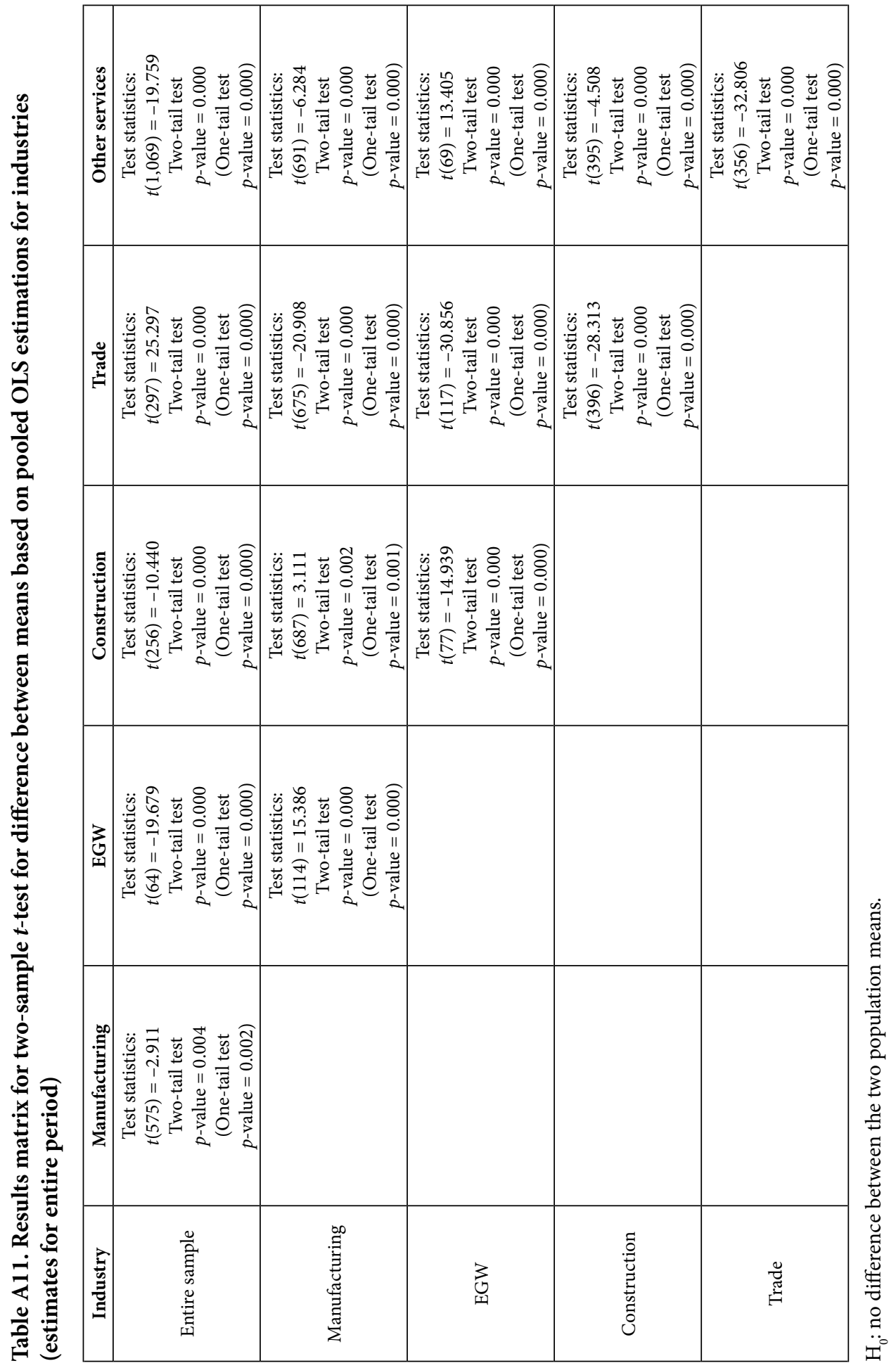




\section{References}

Aguerrevere, F. L. (2009). Real options, product market competition, and asset returns, Journal Finance, 64, 957-983.

Arellano, F., \& Scofield, B. (2014). A ratio-based equation for operating leverage, Academy of Accounting and Financial Studies Journal, 18(4), 1-6.

Baltagi, B. H., \& Li, Q. (1990). A Lagrange multiplier test for the error components model with incomplete panels, Econometric Reviews, 9, 103-107.

Baum, C. F. (2000). XTTEST3: Stata module to compute Modified Wald statistic for groupwise heteroskedasticity. Retrieved from http://EconPapers.repec.org/ RePEc:boc:bocode:s414801

Breusch, T. S., \& Pagan, A. R. (1980). The Lagrange multiplier test and its applications to model specification in econometrics. Review of Economic Studies, 47, 239-253.

Brigham, E. F. (1995). Fundamentals of corporate finance. Orlando, FL: The Dryden Press.

Bureau van Dijk (2016). A database of comparable financial information for public and private companies across Europe Amadeus, Bureau van Dijk Electornic Publishing, update number 262. Retrieved 31 July 2016, from Amadeus website, http://amadeus.bvdinfo.com

Carlson, M., Fisher, A., \& Giammarino, R. (2004). Corporate investment and asset price dynamics: implications for the cross section of returns, Journal of Finance, 59, 2577-2603.

Drukker, D. M. (2003). Testing for serial correlation in linear panel-data models. Stata Journal, 3, 168-177.

Dugan, M., \& Shriver, K. (1992). An empirical comparison of alternative methods for the estimation of the degree of operating leverage. The Financial Revue, 27(2), 309-321.

Greene, W. H. (2000). Econometric Analysis. New Jersey: Prentice Hall, Pearson Education, Inc.

Gulen. H., Xing, Y., \& Zhang, L. (2011). Value versus growth: time-varying expected stock returns. Financial Management 40(2), 381-407.

Hausman, J. A. (1978). Specification tests in econometrics. Econometrica 46, 1251-1271.

Lev, B. (1974 September). On the association between leverage and risk. Journal of Financial and Quantitative Analysis, 9, 627-642.

Mandelker, G., \& Rhee, S. G. (1984 March). The impact of the degrees of operating and financial leverage on systematic risk of common stock. Journal of Financial and Quantitative Analysis, 45-57.

Novy-Marx, R. (2011). Operating leverage. Review of Finance, 15, 103-134.

O'Brien, T., \& Vanderheiden, P. (1987). Empirical measurement of operating leverage for growing firms. Financial Management, 16, 45-53.

Wooldridge, J. (2002). Econometric analysis of cross section and panel data. Cambridge, MA: MIT Press. 